\title{
Editorial \\ On the Way for Patients with Prostate Cancer to the Best Use of PSMA
}

\author{
Finn Edler von Eyben ${ }^{1, *}$, Glenn Bauman ${ }^{2}$, Daniel S. Kapp ${ }^{3}$, Irene Virgolini ${ }^{4}\left(\mathbb{C}\right.$ and Giovanni Paganelli ${ }^{5}$ (i) \\ 1 Center for Tobacco Control Research, Birkevej 17, 5230 Odense, Denmark \\ 2 Department of Oncology, Schulich School of Medicine \& Dentistry, Western University of Ontario, \\ 1151 Richmond Street, London, ON N6A 3K7, Canada; glenn.bauman@lhsc.on.ca \\ 3 Department of Radiation Oncology, The Stanford University School of Medicine, Stanford, CA 94305, USA; \\ dskapp@stanford.edu \\ 4 Department of Nuclear Medicine, University Hospital in Innsbruck, Anichstrasse 35, 6080 Innsbruck, Austria; \\ irene.virgolini@i-med.ac.at \\ 5 IRCCS-Istituto Romagnolo Studio Tumori (IRST) “Dino Amadori”, Via Pietro Maroncelli 40, \\ 47014 Meldola, Italy; giovanni.paganelli@irst.emr.it \\ * Correspondence: finn113edler@mail.tele.dk
}

Citation: von Eyben, F.E.; Bauman, G.; Kapp, D.S.; Virgolini, I.; Paganelli, G. On the Way for Patients with Prostate Cancer to the Best Use of PSMA. Int. J. Mol. Sci. 2022, 23, 2478. https://doi.org/10.3390/ ijms23052478

Received: 7 February 2022 Accepted: 17 February 2022 Published: 24 February 2022

Publisher's Note: MDPI stays neutral with regard to jurisdictional claims in published maps and institutional affiliations.

Copyright: (C) 2022 by the authors. Licensee MDPI, Basel, Switzerland. This article is an open access article distributed under the terms and conditions of the Creative Commons Attribution (CC BY) license (https:// creativecommons.org/licenses/by/ $4.0 /)$.
In recent years, the prostate-specific membrane antigen (PSMA) has achieved a significant role in the diagnostics and treatments of patients with prostate cancer. Guidelines by the European Association of Urology (EAU) and the European Society of Medical Oncology (ESMO) recommend that patients who develop a recurrence after initial treatment with prostate-specific antigen (PSA) relapse undergo restaging PSMA PET/CT scans $[1,2]$. ESMO, the American Urology Association (AUA) and the Danish Prostate Cancer Study Group (DAPROCA) favor an early timescale for the restaging of PSMA PET/CT.

In 2021, the Federal Drugs Administration (FDA) approved restaging with a $\left[{ }^{68} \mathrm{Ga}\right] \mathrm{Ga}-$ 18 PSMA PET/CT at two United States (U.S.) institutions with a high expertise, following a randomized controlled trial [3]. In May 2021, the FDA also approved the routine use of $\left[{ }^{18} \mathrm{~F}\right]$ FCG PyL PSMA PET/CT following two prospective single-arm studies, the CONDOR and the OSPREY trials [4,5]. Consensus documents on the acquisition of PSMA PET/CT, and a standardization of reporting on PSMA PET imaging, are emerging [6-9].

Although these guidelines and approvals indicate that the role of PSMA PET/CT is becoming increasingly established, access to PSMA PET/CT at a systemic level remains variable across jurisdictions, depending on regulatory environments [10].

The present issue of the International Journal of Molecular Sciences (IJMS) includes publications on staging using PSMA PET for the initial management of patients with prostate cancer [11] and on restaging using PSMA PET/CT for patients with prostate cancer at PSA relapse [12-15]. Other publications report the impact of the chemical structure of small inhibitory molecules for the PSMA receptor [16], animal models of PSMA and prostate cancer [17], and associations between the androgen receptor signal transduction pathway and the expression of PSMA [18-20].

Two randomized controlled trials, the TheraP and the VISION trial, proved the therapeutic efficacy of $\left[{ }^{177} \mathrm{Lu}\right] \mathrm{Lu}-177$ radioligand therapy (PRLT) as the third-line systemic treatment of patients with castration-resistant metastatic prostate cancer (mCRPC). A network meta-analysis of randomized trials of third-line systemic treatments of patients with mCRPC showed that PRLT gave the highest reported rate of 50\% PSA decline after the treatments [21]. The FDA conducts an evaluation of PRLT as treatment of patients with mCRPC.

This Special Issue of IJMS also includes studies and reviews that report the adverse effects of PRLT [22] and clinical and nuclear medicine aspects that might contribute to optimizing the treatment of patients with mCRPC with PRLT [23]. 
Thus, this Special Issue of IJMS indicates the state of the art pointing to PSMA as a useful tool for the diagnosis and treatment of patients with prostate cancer. Specialists in nuclear medicine have an increasing role in multidisciplinary teams responsible for the treatment of patients with PSA relapse and mCRPC. In this Special Issue of the IJMS, the Editor and many authors collaborated to help physicians, patients, and others involved continue to better define the clinical impact and integration of PSMA theranostics across the disease spectrum of prostate cancer.

Author Contributions: Conceptualization: F.E.v.E.; original draft preparation: F.E.v.E. and G.B.; review and editing: F.E.v.E., G.B. and D.S.K.; supervision I.V. and G.P. All authors have read and agreed to the published version of the manuscript.

Funding: This editorial received no external funding.

Conflicts of Interest: The authors declare no conflict of interest.

\section{References}

1. Cornford, P.; van den Bergh, R.C.N.; Briers, E.; van den Broeck, T.; Cumberbatch, M.G.; De Santis, M.; Fanti, S.; Fossati, N.; Gandaglia, G.; Gillessen, S.; et al. EAU-EANM-ESTRO-ESUR-SIOG guidelines on prostate cancer. Part II-2020 update: Treatment of relapsing and metastatic prostate cancer. Eur. Urol. 2021, 79, 263-282. [CrossRef] [PubMed]

2. Parker, C.; Castro, E.; Fizazi, K.; Heidenreich, A.; Ost, P.; Procopio, G.; Tombal, B.; Gillessen, S.; on behalf of the ESMO Guidelines Committee. Prostate cancer: ESMO clinical practice guidelines for diagnosis, treatment and follow-up. Ann. Oncol. 2020, 31, 1119-1134. [CrossRef] [PubMed]

3. Hofman, M.S.; Lawrentschuk, N.; Francis, R.J.; Tang, C.; Vela, I.; Thomas, P.; Rutherford, N.; Martin, J.M.; Frydenberg, M.; Shakher, R.; et al. Prostate-specific membrane antigen PET-CT in patients with high-risk prostate cancer before curative-intent surgery or radiotherapy (proPSMA): A prospective, randomised, multicentre study. Lancet 2020, 395, 1208-1216. [CrossRef]

4. Morris, M.J.; Rowe, S.P.; Gorin, M.A.; Saperstein, L.; Pouliot, F.; Josephson, D.; Wong, J.Y.C.; Pantel, A.R.; Cho, S.Y.; Gage, K.L.; et al. Diagnostic performance of ${ }^{18} \mathrm{~F}$-DCFPyL-PET/CT in men with biochemically recurrent prostate cancer: Results from the CONDOR Phase III, multicenter study. Clin. Cancer Res. 2021, 27, 3674-3682. [CrossRef]

5. Pienta, K.J; Gorin, M.A.; Rowe, S.P.; Carroll, P.R.; Pouliot, F.; Probst, S.; Saperstein, L.; Preston, M.A.; Alva, A.S.; Patnaik, A.; et al. A Phase 2/3 prospective multicenter study of the diagnostic accuracy of Prostate-Specific Membrane Antigen PET/CT with ${ }^{18} \mathrm{~F}-\mathrm{DCFP} y \mathrm{~L}$ in prostate cancer patients (OSPREY). J. Urol. 2021, 206, 52-61. [CrossRef] [PubMed]

6. Fanti, S.; Minozzi, S.; Morigi, J.J; Giesel, F.; Ceci, F.; Uprimny, C.; Hofman, M.S.; Eiber, M.; Schwarzenbock, S.; Castellucci, P.; et al. Development of standardized image interpretation for 68Ga-PSMA PET/CT to detect prostate cancer recurrent lesions. Eur. J. Nucl. Med. Mol. Imaging 2017, 44, 1622-1635. [CrossRef]

7. Ceci, F.; Oprea-Lager, D.E.; Emmett, L.; Adam, J.A.; Bomanji, J.; Czernin, J.; Eiber, M.; Haberkorn, U.; Hofman, M.S.; Hope, T.A.; et al. E-PSMA: The EANM standardized reporting guidelines v1.0 for PSMA-PET. Eur. J. Nucl. Med. Mol. Imaging 2021, 48, 1626-1638. [CrossRef]

8. $\quad$ Eiber, M.; Herrmann, K.; Calais, J.; Hadaschik, B.; Giesel, F.L.; Hartenbach, M.; Hope, T.; Reiter, R.; Maurer, T.; Weber, W.A.; et al. Prostate Cancer Molecular Imaging Standardized Evaluation (PROMISE): Proposed miTNM Classification for the Interpretation of PSMA-Ligand PET/CT. J. Nucl. Med. 2018, 59, 469-478. [CrossRef]

9. Werner, R.A.; Thackeray, J.T.; Pomper, M.G.; Bengel, F.M.; Gorin, M.A.; Derlin, T.; Rowe, S.P. Recent Updates on Molecular Imaging Reporting and Data Systems (MI-RADS) for Theranostic Radiotracers-Navigating Pitfalls of SSTR- and PSMA-Targeted PET/CT. J. Clin. Med. 2019, 8, 1060. [CrossRef]

10. Shaygan, B.; Zukotynski, K.; Benard, F.; Menard, C.; Kuk, J.; Sistani, G.; Bauman, G.; Veit-Haibach, P.; Metser, U. Canadian Urological Association best practice report: Prostate-specific membrane antigen positron emission tomography/computed tomography (PSMA PET/CT) and PET/magnetic resonance (MR) in prostate cancer. Can. Urol. Assoc. J. 2021, 15, 162-172. [CrossRef]

11. Mapelli, P.; Ghezzo, S.; Gajate, A.M.S.; Preza, E.; Brembilla, G.; Cucchiara, V.; Ahmed, N.; Bezzi, C.; Presotto, L.; Bettinardi, V.; et al. Preliminary results of an ongoing prospective clinical trial on the use of ${ }^{68} \mathrm{Ga}$-PSMA and ${ }^{68} \mathrm{Ga}$-DOTA-RM2 PET /MRI in staging of high-risk prostate cancer patients. Diagnostics 2021, 11, 2068. [CrossRef] [PubMed]

12. Von Eyben, F.E.; Soydal, C.; von Eyben, R. ${ }^{68}$ Ga-PSMA PET/CT for patients with PSA relapse after radical prostatectomy or external beam radiotherapy. Diagnostics 2021, 11, 622. [CrossRef] [PubMed]

13. Jonmarker, O.; Axelsson, R.; Nilsson, T.; Gabrielson, S. Comparison of regularized reconstruction and ordered subset expectation maximization reconstruction in the diagnostics of prostate cancer using digital time-of-flight ${ }^{68} \mathrm{Ga}$-PSMA-11 PET/CT imaging. Diagnostics 2021, 11, 630. [CrossRef] [PubMed]

14. Vlachostergios, P.J.; Zachos, I.; Tzortzis, V. Biomarkers in prostate-specific membrane antigen theranostics. Diagnostics 2021, 11, 1108. [CrossRef] 
15. Bayerschmidt, S.; Uprimny, C.; Kroiss, A.S.; Fritz, J.; Nilica, B.; Svirydenka, H.; Decristoforo, C.; von Guggenberg, E.; Horninger, W.; Virgolini, I.J. Comparison of early imaging and imaging $60 \mathrm{~min}$ Post-Injection after forced diuresis with furosemide in the assessment of local recurrence in prostate cancer patients with biochemical recurrence referred for 68Ga-PSMA-11 PET/CT. Diagnostics 2021, 11, 1191. [CrossRef] [PubMed]

16. Debnath, S.; Zhou, N.; Mclaughlin, M.; Rhee, S.; Pillai, A.; Hao, G.; Sun, X. PSMA-Targetting imaging and theranostic agentscurrent status and future perspective. Int. J. Mol. Sci. 2022, 23, 1158. [CrossRef] [PubMed]

17. Stenberg, V.Y.; Larsen, R.H.; Ma, L.W.; Peng, Q.; Juzenas, P.; Bruland, O.S.; Juzeniene, A. Evaluation of the PSMA-binding ligand ${ }^{212} \mathrm{~Pb}-\mathrm{NG} 001$ in multicellular tumour spheroid and mouse models of prostate cancer. Int. J. Mol. Sci. 2021, 22, 4815. [CrossRef]

18. Staniszewska, M.; Fragoso Costa, P.; Eiber, M.; Klose, J.M.; Wosniack, J.; Reis, H.; Szarvas, T.; Hadaschik, B.; Luckerath, K.; Herrmann, K.; et al. Enzalutamide enhances PSMA expression of PSMA-low prostate cancer. Int. J. Mol. Sci. 2021, $22,7431$. [CrossRef]

19. Kesler, M.; Druckmann, I.; Levine, C.; Kuten, J.; Yossepowitch, O.; Even-Sapir, E. 68Ga-PSMA-11 PET/CT follow-up of patients with prostate cancer with bone metastases who had reduced bone density after androgen deprivation therapy. Diagnostics 2021, 11, 277. [CrossRef]

20. Sommer, H.; Siciliano, T.; Ebersbach, C.; Beier, A.-M.K.; Stope, M.B.; Jahren, K.; Baretton, G.B.; Borkowetz, A.; Thomas, C.; Erb, H.H.H. Impact of androgen receptor activity on prostate-specific membrane antigen expression in prostate cancer cells. Diagnostics 2022, 23, 1046. [CrossRef]

21. Von Eyben, F.E.; Kairemo, K.; Paller, C.; Hoffmann, M.A.; Paganelli, G.; Virgolini, I.; Roviello, G. ${ }^{177}$ Lu-PSMA radioligand therapy is favorable as third-Line treatment of patients with metastatic castration-resistant prostate cancer. A systematic review and network meta-Analysis of randomized controlled trials. Biomedicines 2021, 9, 1042. [CrossRef] [PubMed]

22. Kesavan, M.; Meyrick, D.; Gallyamov, M.; Turner, J.H.; Yeo, S.; Cardaci, G.; Lenzo, N.P. Efficacy and haematologic toxicity of palliative radioligand therapy of metastatic castrate-resistant prostate cancer with Lutetium-177-labeled prostate-specific membrane antigen in heavily pre-treated patients. Diagnostics 2021, 11, 515. [CrossRef] [PubMed]

23. Von Eyben, F.E.; Bauman, G.; von Eyben, R.; Rahbar, K.; Soydal, C.; Haug, A.R.; Virgolini, I.; Kulkarni, H.; Baum, R.; Paganelli, G. Optimizing PSMA radioligand therapy for patients with metastatic castration-resistant prostate cancer. A systematic review and meta-analysis. Int. J. Mol. Sci. 2020, 21, 9054. [CrossRef] [PubMed] 